\title{
UNFAIR TERMS IN A TENANCY AGREEMENT INVOLVING OFF-CAMPUS STUDENTS: A LEGAL DISCUSSION
}

\author{
Farihana Abdul Razak ${ }^{1}$ \\ Department of Law, \\ Universiti Teknologi MARA Perak Branch Tapah Campus, Malaysia. \\ (Email: farihana@perak.uitm.edu.my) \\ Nurhidha Irawaty Kasmaruddin ${ }^{2}$ \\ Academy of Language Studies, \\ Universiti Teknologi MARA Perak Branch Seri Iskandar Campus, Malaysia. \\ (Email: nurhi9087@ perak.uitm.edu.my) \\ Anuar Kassim ${ }^{3}$ \\ Senior Police Officer, Tapah Police District, 35000 Tapah, Perak, Malaysia. \\ (Email: anuarkassim@rmp.gov.my)
}

Received date: 11-06-2019

Revised date: $30-06-2019$

Accepted date: 02-08-2019

Published date: 05-09-2019

To cite this document: Razak, F. A., Kasmaruddin, N. I., \& Kassim, A. (2019). International Journal of Law, Government and Communication, 4(16), 01-09.

DOI: $10.35631 / \mathrm{ijlgc} .416001$

\begin{abstract}
Some universities in Malaysia with a large number of students enrolled every year cannot cope with the increasing demand for students' accommodation, therefore students have to find rental houses near the university. The purpose of this paper is to explore the unfair terms in a tenancy agreement involving off-campus students and rental house owner. The underlying philosophy is that students who have reached the age of majority and sound mind are free to enter into contracts and must, therefore, understand the legal effects of contract for which they have agreed. This paper gathers data from the tenancy agreement collected by several numbers of students who are staying off-campus at UiTM Perak Branch, Tapah Campus, through references to statutes and case reports to police. Thus, it discussed the legal effects of unfair terms in a tenancy agreement involving off-campus students and this study proposed three recommendation. The first is to educate students on the understanding of the clause in the tenancy agreement and the legal effect for breach of contract, the second is to educate the rental house owners on the importance of fairness clauses for both parties in a tenancy agreement and, thirdly, to recommend the university's non-resident unit under Students Affairs (HEP) to draw up a sample of win-win tenancy agreements as guidelines for both parties. Hopefully, this paper would contribute to the body of knowledge in the area of law of contract.
\end{abstract}

Keywords: Unfair Terms, Tenancy Agreement, Off-Campus Students, Contract, Small Claim Court 


\section{Introduction}

In Malaysia, the current system of higher education is changing. With regards to the development and awareness of society about the importance of higher education, universities have taken a huge intake number of students nowadays. Some universities, however, cannot cope with the large number of students enrolled as college residents due to the increasing demand for students' accommodation and therefore students themselves have to find rental houses or apartments near to campus for their residential needs. Once they enter into a contract with the rental house owner, a legal relationship will be established automatically. However, when the party i.e. students signed the agreement without reading and understanding the terms, they do not acknowledge the legal relationship that was established and if they breach the terms in a contract, they have to face with legal action taken by landlord.

The purpose of understanding the clause or terms in the rental agreement is to ensure that unfair terms can be challenged in court. The contract may be void or voidable once the elements of a valid contract is not fulfilled. Off-campus students are often given standardized drafted agreements by the rental house owners that have been prepared beforehand to fully protect the landlord without discussing tenants who, in reality, are off-campus students whom have no choice but to sign the rental agreement by 'take-it or leave-it basis'. Contracts were provided on the grounds of 'take-it or leave-it', that fact alone do not make it a normal agreement form. It is essential that the parties were highly disparate in bargaining power, that there was no negotiating opportunity, or that the services could not have been obtained elsewhere (Articles, 2017).

The objective of this study is to analyse the unfair terms in a tenancy agreement referred to five samples of the tenancy agreement entered into by selected off-campus students in UiTM Perak Branch, Tapah Campus and to discuss the legal effect of unfair terms in a contract and to give recommendations pertaining to this issues.

\section{Literature Review}

\section{Contract}

In Malaysia, contract defined as what was stipulated in the Contracts Act, 1950 (Act 136) (Revised 1974). If there is no provision made or covered by the Contracts Act or if a particular subject has been covered by the Contracts Act but there are no provisions relating to the subject matter, in other words, the subject matter is not exhaustive, English law is applied under the Civil Law Act.

Section 24A(a) of the Consumer Protection (Amendment) Act 2010 (hereinafter referred to as "CPA (Amendment) 2010"), provides the definition of contract as same meaning as assigned to it in Section 2 of the Contracts Act 1950 (hereinafter referred to as "CA 1950"). Section 2 of the CA 1950 provides:

a) "When one person signifies to another his willingness to do or to abstain from doing anything, with a view to obtaining the assent of that other to the act or abstinence, he is said to make a proposal;

b) When the person to whom the proposal is made signifies his assent thereto, the proposal is said to be accepted: a proposal, when accepted, becomes a promise;

c) The person making the proposal is called the "promisor' and the person accepting the proposal is called the "promisee"; 
d) When, at the desire of the promisor, the promisee or any other person has done or abstained from doing, or does or abstains from doing, or promises to do or to abstain from doing, something, such act or abstinence or promise is called a consideration for the promise;

e) Every promise and every set of promises, forming the consideration for each other, is an agreement;

f) Promises which form the consideration or part of the consideration o part of the consideration for each other are called reciprocal promises;

g) An agreement not enforceable by law is said to be void;

h) An agreement enforceable by law is a contract;

i) An agreement which is enforceable by law at the option of one or more of the parties thereto, but not at the option of the other or others, is a voidable contract; and

j) A contract which ceases to be enforceable by law becomes void when it ceases to be enforceable."

To enter into a contract, both parties must reach the age of majority, sound mind and are not disqualified by any law to which they are subject under section 11 of the CA 1950.

\section{Tenancy Agreement involving Off-Campus Students}

Off-campus students are bound by the University regulations but not bound by the residential college rules. In fact, the management of the university does not monitor these students as they are beyond the control of the university authority. Therefore, in dealing with external and internal issues they need to take care of themselves (Rohanah Hamzah, N A F Baharuddin and Z Ali, 2019). Since off-grounds living undergrads need to settle without their family outside of the grounds, they are facing issues in a few divisions such as house rent, security, nourishment, transportation, doing goods, and etc. In addition, non-residential students face various problems, such as confrontation with neighbourhood disputes, severed landlords and landlady relationships, noise problem, environmental pollution, shortage of resting places, frequent shortages of water, and disputes over monthly electricity bills payment, etc (Sen and Antara, 2018). Furthermore, they have to enter into a tenancy agreement to stay at a rental house.

A tenancy agreement is defined as a contractual relationship between a landlord, known as rental house owner and a tenant that requires the occupant to pay rental for reside in the property. In addition, off-campus students who wish to sign a tenancy agreement must ensure that they have entered into the agreement by free consent, with the contracting parties competent for a lawful consideration and with a lawful object as provided in section 10(1) of the CA 1950.

\section{Unfair Terms in a Contract}

In recent times the subject of 'unfair contract terms' has gained serious significance. Not only with respect to consumer contracts, but also with respect to other contracts. In the context of tremendous expansion in trade and business, as well as consumer rights, the topic has now assumed great importance (Sakina Shaik, Mohamed Isa and Azimon, 2012). Unfair contract term can be described as 'a term that disadvantages a party to a contract whereas the term is not sufficiently essential to protect the other party's interests' (Alexandra, 2013).

Section 24A(c) of the CPA (Amendment) 2010 states that "unfair term" means a term in a consumer contract that causes a significant imbalance in the rights and obligations of the parties arising from the contract to the detriment of the consumer in all circumstances. Section 24B of 
the CPA (Amendment) 2010 provides for all contracts without prejudice to the provisions in the Contracts Act 1950, the Specific Relief Act 1950 [Act 137], the Sale of Goods Act 1957 [Act 382] and the provisions of any other law in force in time being.

Section 24D (1) of the CPA (Amendment) 2010 states a contract or a term of a contract is substantively unfair if the contract or the term of the contract-

a) 'is in itself harsh';

b) is oppressive;

c) is unconscionable;

d) excludes or restricts liability for negligence; or

e) excludes or restricts liability for breach of express or implied terms of the contract without adequate justification."

Section 24G(1) of the CPA (Amendment) 2010 provides that where a court or tribunal reaches a conclusion on the basis of sections $24 \mathrm{C}$ and 24D that a contract or a term of a contract is either procedurally or substantially unfair or both, the court or tribunal may declare the contract or term of the contract to be unenforceable or void and the court may give judgment, and the tribunal may make an award as provided for under section 112 of this Act.

By virtue of section 24(2)(g) of the CPA (Amendment) 2010, a contract or term in a contract may be declared unfair either because of lack of transparency or lack of negotiating power or lack of consumer choice or other disabilities provides that the court or tribunal may also consider 'whether or not, even if the consumer is competent to enter into a contract:

a) "was not reasonably able to protect his or her own interests or of those whom he or she represented at the time the contract was entered; or

b) Suffered serious disadvantages in relation to other parties because the consumer was unable to appreciate adequately the contract or a term of the contract or its implications by reason of age, sickness, or physical, mental, educational or linguistic disability, or emotional distress or ignorance of business affairs." (Naemah Amin, 2013).

If there is an element of unconscionable bargain in the contract, for example, absence of negotiation of such agreements along with illegibility and incomprehensibility of numerous clauses and assenting to terms under circumstances with absolutely no room for negotiation must not be misunderstood as 'free consent' (Norhadizah et al., 2017). However, an argument against contract provisions like termination-at-will clauses is that they seem to favour one party at another's expense. It is therefore alleged that the terms of the agreement must have been reached under "unequal bargaining power" conditions and should therefore be invalid (Klien, 1980).

\section{Methodology}

This study adopts a doctrinal or otherwise known as methodology of pure legal research. Doctrinal research is a study of the doctrine of law and practice and is largely documentary. It concentrates on the cases, rules and principles. Doctrinal legal research involves an in-depth analysis of the legal doctrine with its process of development and legal reasoning, whereas nondoctrinal research seeks different social facts, the relationship of law to these facts, the impact of law on society and so on (Amrit, 2018). This study gathers data from primary and secondary sources and analyses it. The primary data were collected from five samples of tenancy 
agreement entered by UiTM off-campus students in Tapah as a contracting parties in the through cases report to police at Tapah Police District regarding rental house and references to statutes. Secondary data were collected from journal and articles.

\section{Discussion and Recommendation}

A promise or agreement between the parties must be valid and binding in order for a contract to be enforceable; that is, they must be capable of being legally classified as agreements that are valid and legally binding (Nik Malini et al., 2011). In order to protect contracting parties' interests and rights, a specific tenancy law is required to create a level playing field to regulate the relationships between landlords and tenants. The intervention of such a specific law will direct and guide both parties as to which contractual terms may be inserted into the tenancy agreement, balancing the inequality in their bargaining power, thus ensuring favourable protection for the parties involved.

Student housing is essential for achieving quality education, especially in higher institutions where students come from a distance to study (Douglas et al., 2019). The case study selected in this study was tenancy agreement of students from Universiti Teknologi Mara (UiTM) Perak Branch, Tapah Campus. It is located in Tapah Road, Perak's rural area. UiTM is Malaysia's leading higher learning institution, which has experienced tremendous growth since its commencement in 1956. Tapah campus is one of the branch campuses of UiTM Perak. Based on the selected samples of a tenancy agreement, several unfair terms were found such as:

i. Owner have right to order the tenant to return the premises immediately without giving any notice.

ii. Owner have right to terminate the contract without any refund and damages to tenant.

iii. It is right of the owner to terminate the contract without further discussion with the tenant.

iv. The tenant has to find a replacement to continue renting the rental houses if they have finished their study and if they failed to find replacement, the deposit will not be returned.

v. Any disputes between tenant and owner cannot be settled in court.

As regards to the unfair terms found in a tenancy agreement involving off-campus students in UiTM Perak Branch, Tapah Campus, this study proposed three recommendation.

\section{Educate Off-Campus Students as regards to Tenancy Agreement}

Off-campus students at UiTM Tapah campus must be registered under the Non-Resident (NR) unit for recording and monitoring off-campus students, as well as providing assistance when necessary especially if they have problems during their stay. Some students may not know the NR unit's existence, furthermore, and they are not registered with the unit. Details of UiTM Tapah off-campus students who were registered with the NR unit in 2017 and 2018 are presented in Table 1. 
Table 1: Number of Off-Campus Students Who Registered with NR Unit at Uitm Tapah Campus for Year 2017-2018

\begin{tabular}{ll}
\hline Year/Semester & Number of registered off-campus students \\
\hline December 2016- April 2017 & 400 \\
\hline September 2017 - January 2018 & 1400 \\
\hline March - July 2018 & 800 \\
\hline September 2018 - January 2019 & 1600 \\
\hline Source: Non-Resident Unit UiTM Perak Branch, Tapah Campus (2019).
\end{tabular}

The increasing number of students who stay outside the campus forced them to face tenancy agreements before rental accommodation. Basically, students who frequently deal with tenancy agreements are between the ages of 18 to 22 years of age.

The first recommendation as regards to this issues is to educate off-campus students on the understanding of the clause in the tenancy agreement. For off-campus students, the most important reason for understanding the rental agreement is to protect themselves from unfair terms in a contract together to know the rights and the consequences if one of the parties breach the agreement clause and terms. In most cases, on a 'take it or leave it' basis, the conditions in agreement offered to students contains unfair terms. However, the rental house is needed for off-campus students who have been looking for a rental house near their campuses and they ignored the unfair terms in the agreement.

Sometimes, the terms and conditions in the tenancy agreement may be extremely harsh against the students because their rights as a tenant may be limited or restricted or all together denied. For example, the clauses require tenant to find a replacement if they have finished their study and if they failed to find replacement, the deposit will not be returned. Other than that, a clause regarding the right of owner to terminate the contract without further discussion with the tenant is one of exemption clauses that exclude the liability of the owner towards the tenant. This is considered as unfair terms in a tenancy agreement.

Although management of the university will not be involved in any dispute outside campus, NR unit of the university can play a good role by having a meeting with off-campus students and give them talk with regards to contract. NR unit can invite any law lecturer in the university to give the students' knowledge about tenancy agreement. This is very important prevent any dispute among students as tenants with the rental house owner and to give students a better explanation about the effects in entering into a tenancy agreement.

\section{Educate Rental House Owners on the Fairness of the Tenancy Agreement}

The formation of contract law dictates that the parties to a contract must be of the same mind, that consensus ad idem must be established. In the context of the standard form contract, the standard terms used in the offer must be expressed to the other party before acceptance takes place in order to establish the meeting of minds (Azimon and Sakina, 2010). Consensus ad idem or meeting of the mind is a doctrine of common law that requires all contracting parties to understand and accept the obligations and conditions set out in the agreement. Consensus adidem as a concept has been incorporated into section 13 of the CA 1950, which defines 'consent' as if in the same sense two or more people agree on the same thing (Nik Ahmad Kamal, et al., 2017). 
The impacts of tenancy agreements entered by accommodation for off-campus students with landlord cannot be ignored. One of the impacts is the contract is legally binding where it can sue and be sued. Next, if the contract involves with the elements of no free consent, it is a voidable contract especially when the contract can be proved by innocent parties in court. Under Section 14 of the CA 1950, consent must be free and not caused by misrepresentation, undue influence, mistake, coercion and fraud. If there is no free consent, the tenancy agreement is concerned with unfairness clause. Even the law ensures that the rules are fair, but when the fairness of rules were followed, especially in the tenancy agreement, it does not concern the result.

Apart from the absence of negotiation, there is also the issue of terms being ignored, and this was also a major bone of contention (Mohd Faiz and Rozanah, 2015). According to Royal Malaysia Police statistic, in 2017, 21 cases were reported at Tapah Police District and 23 cases involving rental houses were reported in 2018. It is shown in Table 2.

Table 2: Police Report on Rental House in Tapah, Perak

\begin{tabular}{ll}
\hline Year & Number of cases \\
\hline 2017 & 21 cases \\
\hline 2018 & 23 cases \\
\hline
\end{tabular}

Source: Royal Malaysia Police (2019).

Based on Table 2, it shows a growing number of cases year after year and the right consciousness as the rental house's tenant and landlord.

The second recommendation is to educate the rental house owners on the fairness of the tenancy agreement. It is very important for the rental house owners understand the legal effect on the unfairness of the tenancy agreement because they are the one who prepared the tenancy agreement. Furthermore, they cannot simply draft a tenancy agreement and include exclusion clauses which are unfair to the tenant.

As a person who are sui juris, a tenant can take a legal action towards the owner if the tenancy agreement contains unfairness of terms. In Nur Aini Zurnizam \& Anor v. Azmi Asaad and Anor, case number AD-A77-2-11/2017, the magistrate ruled that the defendants had breached the contract by demanding the plaintiffs to vacate the said premise and court held that the defendants have to pay the plaintiffs a sum of RM 2240.00 with cost of RM 100.00. This case was heard in a Small Claim Court involving Part 3 students of Diploma in Accountancy, UiTM Perak Branch, Tapah Campus on 22 January 2018 against landlord.

\section{Non-Resident Students Affairs Unit (HEP) Roles}

The third is to recommend the university's non-resident students affairs unit (HEP) to sample a win - win tenancy agreement as guidelines for both parties. Even though the management of university does not monitor the off-campus students, as a higher educational institution, it is of a benefit to the institution if the management can provide information, guidelines and a proper sample of fairness tenancy agreement for the benefit of both parties i.e. students and landlord as a corporate social responsibility in higher education. Corporate Social Responsibility (CSR) implies the duty of the organization to protect and improve the welfare of society and its organisation by means of its various business and social actions, now and in the future, and guarantees that it generates equitable and sustainable benefits for the various stakeholders 
(Hardeep and Sharma, 2006). In this circumstance, students are considered as University's stake holder. It is hoped that both parties will freely consent to enter into the tenancy agreement with the proposed recommendation.

\section{Conclusion}

While off-campus students need to find a residential rental house, they need to read and understand the contract, so they will know their right, the contract with fair term which not abuse one party, and the legal effect of entering into a contract. Most tenancy agreements are couple of pages long thus they will take time to read and review. The consequences that students outside campus need to know are the innocent party in the contract has the right to sue and be sued whether as a tenant or as a landlord or rental house owner if any party breaches the contract because the contract, they have entered into is legally binding on the parties concerned.

\section{References}

Ahmad Yusoff, S. S., Isa, S. M., \& Aziz, A. A. (2012). Legal Approaches to Unfair Consumer Terms in Malaysia, Indonesia and Thailand. Pertanika J.Soc. Sci. \& Hum. 20 (S), 4355.

Alexandra, S. (2013). Unfair Contract Terms: A New Dawn in Australia and New Zealand. Monash University Law Review Vol 39, No 3: 739-775.

Amrit, K. (2018). Doctrinal Legal Research. SSRN Electronic Journal, 1-16.

Articles, L. (23 June, 2017). Standard Form of Contracts - Take it or Leave it? India.

Azimon, A. A., \& Sakina, S. A. (2010). Regulating Standard Form of Consumer Contracts: The Legal Treatment of Selected Asian Jurisdiction. Asian Journal of Accounting and Governance, 105-124.

Douglas, A., Clinton, A., Joshua, A., \& Wellington, T. (2019). Students' Housing Satisfaction in Private Higher Institutions. Interdependence between Structural Engineering and Construction Management, 1-6.

Hardeep, C., \& Sharma, R. (2006). Implications of Corporate Social Responsibility on Marketing Performance: A Conceptual Framework. Journal of Services Research, 205216.

Klien, B. (1980). Transactions Costs Determinants of "Unfair" Contractual Arrangements. The American Economic Review, 356-362.

Mohd. Faiz, A., \& Rozanah, A. (2015). Consent, Standard Form Contracts and Empowerment for Consumers. Journal of Scientific Research and Development 2 (14): 68-73.

Naemah, A. (2013). Protecting Consumer against Unfair Contract Terms in Malaysia: The Consumer Protection (Amendment) Act 2010. [2013] 1 MLJ ixxxix.

Nik Ahmad Kamal, N., Ida Madieha, A., Engku Rabiah Adawiah, E., Wan Abdul Fattah, W., Mahyuddin, D., \& Mohammad Deen, M. (2017). An Analysis of Consensus Ad Idem: The Malaysian Contract Law and Shari'ah Perspective. Pertanika J. Soc. Sci. \& Hum, 73-84.

Nik Malini, N., Nur Izzati, M., Nurul Hasliza, R., \& Nur Dalila, M. (2011). Enforceable Contracts: Intention To Create Legal Relations. Malaysia: UMK ePrints.

Non-Resident Unit UiTM Perak Branch, Tapah Campus (2019).

Norhadizah, M., Elistina, A., Norhasmah, S., \& Mohamad Fazli, S. (2017). Consumer Protection in the Aviation Industry in Malaysia. Malaysian Journal of Consumer, 92105.

R Hamzah, N A F Baharuddin and Z Ali. (2019). Development of Leadership Transformation Module for Off-Campus Students. IOP Conference Series: Materials Science and 
Engineering, available at https://iopscience.iop.org/article/10.1088/1757 899X/506/1/012017/pdf accessed on 20 July 2019

Royal Malaysia Police (PDRM), 2019.

Sen, S., \& Antara, N. (2018). Influencing Factors to Stay Off-Campus Living by Students. International Multidisciplinary Research Journal, 40-44.

\section{Legislation}

Contracts Act 1950.

Consumer Protection Act 1999 (Amendment 2010).

\section{Court case}

Nur Aini Zurnizam \& Anor v. Azmi Asaad and Anor, case number AD-A77-2-11/2017 (Small Claim Proceeding in Tapah magistrate Court). 